\title{
Effects of pen colour and photoperiod interactions on the performance and
}

\author{
respiratory rate of finisher gilts \\ ${ }^{1}$ Adelowo, O. V., ${ }^{2}$ Adebiyi, O. A. and ${ }^{2}$ Odu, O. \\ ${ }^{I}$ Animal Production Department, Federal Collegeof Animal Health and \\ Production Technology, Vom, Plateau State, Nigeria \\ ${ }^{2}$ Department of Animal Science, University of Ibadan, Ibadan, Nigeria \\ Abstract Corresponding author: olufisayo71@gmail.com; +2348030426283
}

This study was carried out to investigate the effects of pen colour and photoperiod interactions on the performance and respiratory rate of gilts at finisher stage. Thirty-six crossbred (Large white $x$ Landrace) gilts of mean body weight of $38.12 \pm 0.59 \mathrm{~kg}$ were randomly allotted to four (4) treatments. Pens were painted with different colours: pantone441 (control), pantone293 (blue), pantone185 (red) and pantone361 (green) and exposed to photoperiods of 12,15 and 18 hours $(h)$. The experimental design was $3 \times 4$ factorial arrangement in a completely randomised design. Performance parameters measured were Feed Intake (FI), Final Weight (FW) and Weight Gain (WG), while Feed Conversion Ratio (FCR) was calculated weekly throughout the eight weeks of the experiment. Respiratory and rectal temperatures were also monitored. The main effect of pen colour was not significant $(p>0.05)$ on $F W$ and $W G$ across the treatments while there were no significant variations $(p>0.05)$ in the values of FI and FCR of the gilts due to pen colour. The respiratory rate varied significantly $(p<0.05)$ with gilts in red pen $(46.64 \pm 2.32)$ having the highest value. Photoperiod had no significant $(p>0.05)$ effects on $F W$ and $W G$, while FI and $F C R$ had significant $(p<0.05)$ variation across the treatments $[12 \mathrm{~h} . \quad(5.05 \pm 0.37), 18 \mathrm{~h}$

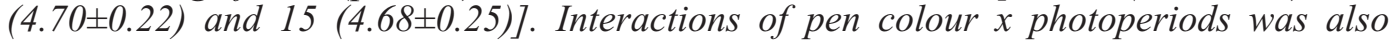
significant for FW, WG, FCR and FI. It can therefore be concluded that rearing gilts at finisher stage in green, blue or red pens gives optimal performance and photoperiod of 12 hours gives maximum production.

Keywords: finisher gilts, growth, respiratory rate, photoperiod and pen colour

\section{Introduction}

Photoperiod can be defined as the duration of light experienced by an organism (Adelowo, 2017). Pigs are intelligent, adaptable, social animal which are sensitive to their environment with ability to discriminate colours as reported by Adelowo and Adebiyi (2016). Vision is used to some extent during foraging and pigs show the ability to recognise and associate a colour with food source (Nicol and Pope, 1994; Croney et al., 2003). Pigs have a wide angle of vision $310^{\circ}$ (Prince, 1977; Taylor, 2010; Adelowo and Adebiyi, 2016) thus, have a panoramic view of their surroundings. Hendrickson and Hicks (2000) explained the distribution of the rods and cones in the porcine retina which suggested adaptations for best acuity in the horizontal panorama from the eye, with good levels maintained for observing objects from eye-level down to the ground, but relatively uniform distribution of cone types within this area suggesting that there is no specific spectrally sensitive area, with the whole retina equally capable of detecting colour information. The radiation wavelengths to which pigs are maximally sensitive are slightly lower than those for humans, within the range of 465-680 nm, pigs can distinguish wavelength differences as small as $20 \mathrm{~nm}$ (Signoret et al., 1975). The retina of pigs contains a substantial population of two types of cones with sensitivity peaks at about 439 $\mathrm{mm}$ (indigo) and $556 \mathrm{~mm}$ (green-yellow) in the spectrum of visible light (Neitz and Jacobs, 1989) and pig is thus believed to 


\section{Effects of pen colour and photoperiod interactions on finisher gilts}

have dichromatic colour vision.

In swine production, temperature and light are viewed as major environmental factors that affects animal physiology (Andersson et al., 1998; Rivera et al., 2005; Adebiyi and Adelowo, 2017) with temperature being considered the most important factor. Seasonal changes in pig physiology still occur (Sancho, 2006); thus indicating the importance of artificial lighting programs. Light exposure involves three characteristics of artificial lighting programs: spectrum (color), intensity and photoperiod (Delabbio, 2015). There were reports of notable receptability and increased performance due to colour and photoperiod in pig production according to Adelowo and Adebiyi (2016); Adebiyi and Adelowo (2017). This study investigate effects of pen colour and photoperiod interactions on the performance and respiratory rate of gilts at finisher stage.

\section{Materials and methods}

The study was carried out at the Piggery section, Teaching and Research Farm of the University of Ibadan, Ibadan, Oyo state, south western part of Nigeria. The location is $727 \mathrm{~N}$ and $345 \mathrm{E}$ at altitude $200-300 \mathrm{~m}$ above sea level, the climate is humid tropical with mean temperature of $25-29^{\circ} \square$ and the average annual rainfall of about 1250mm (Adebiyi and Adelowo, 2017). Thirty-six (36) gilts average weight of 38.12 $\pm 0.59 \mathrm{~kg}$ was used for the study. The experimental design was $3 \mathrm{x} 4$ factorial arrangement in a completely randomised design. Three gilts were placed in each of the unit and each gilt represented a replicate. The experimental pens were partitioned into twelve equal parts each with water and feeding trough and the walls were raised with teak plank to prevent the interference and reflections of light rays into the other pens. The pens were painted into three colours: pantone441 (control=T1), red pantone185 (T2), blue pantone293 (T3) and green pantone361 (T4). Electrification of eight pens; Control, (15 and 18 hour), red $(15 \mathrm{~h}$ and $18 \mathrm{~h})$, blue $(15 \mathrm{~h}$ and $18 \mathrm{~h})$, and green $(15 \mathrm{~h}$ and $18 \mathrm{~h})$ to be used for increased photoperiods was done and coloured bulb was installed according to the colour of the pen. The pen used for $12 \mathrm{~h}$ photoperiod (normal daylength) was also coloured. The duration of this experiment for the finisher stage was 8 weeks (two months) and all the parameters were measured weekly. A digital clinical thermometer was used to take the readings of the rectal temperature as described by Morley et al. (1992) and a non-contact infrared thermometer was used to take the body temperature. Temperature and relative humidity of the pen were measured with the aid of a thermo-hygrometer which was suspended in the pen.

\section{Statistical analysis}

Data from the experiment were subjected to statistical analysis of variance (ANOVA) procedure of SAS (2010) and significant level of $\alpha_{0.05}$ was used. The treatment means were compared using the Tukey, HSD of the same software.

\section{Experimental diet for finishers}

The experimental diet consists of the concentrate and a basal diet which were fed in the ratio 40:60. The basal diet consist of palm kernel cake, dried brewer's grain and cassava peel, the three were mixed with the concentrate and fed to the finishers. Table 1 showed the concentrate composition of the finisher diet formulated to meet the NRC (1998) requirements.

\section{Results}

Results of the main effect of pen colour on performance characteristics of finisher gilts are presented in Table 2. The final weight of finisher gilts in the green is heavier compared to other treatments but not significantly $(\mathrm{p}>0.05)$ different (green, blue and red pens values were $58.67 \pm 0.71 \mathrm{~kg}$, $57.67 \pm 1.22 \mathrm{~kg}$ and $57.78 \pm 1.39 \mathrm{~kg}$, respectively) compared to those in control pen $(57.00 \pm 1.22 \mathrm{~kg})$. There was no significant difference in the feed intake of the finisher gilts across the treatments. The average weight gain variation of all the treatments were also not significantly 
Table 1: The gross composition of concentrate fed to the finisher gilts

\begin{tabular}{ll}
\hline Ingredient & Percentage (\%) \\
\hline Maize & 40.00 \\
Wheat offal & 43.50 \\
Soya bean meal & 2.00 \\
Fish meal & 1.25 \\
Groundnut cake & 10.00 \\
Bone meal & 1.00 \\
Oyster shell & 1.00 \\
Lysine & 0.25 \\
Methionine & 0.25 \\
Vit. /Min. Premix & 0.25 \\
Salt & 0.50 \\
Total & 100 \\
Calculated analysis & \\
Crude Protein (\%) & 17.28 \\
Metabolisable energy (kcal/kg ME) & 2523.2 \\
Calcium (\%) & 0.90 \\
Phosphorus (\%) & 0.74 \\
Lysine (\%) & 0.88 \\
Methionine \% & 0.51 \\
Crude fibre (\%) & 5.14
\end{tabular}

$\mathrm{ME}=$ Metabolisable energy, Vit./Min. = Vitamin/Mineral,

*Micro-mix growers \& pigs: $2.5 \mathrm{~kg}$ of premix contains Vitamin A (10,000,000.00i.u); Vitamin D3 (2, 000,000.00i.u); Vitamin E (20,000.00mg); Vitamin K3 (2,000.00mg); Vitamin B1 (3,000.00mg); Vitamin B2 (5,000.00mg); Niacin (45,000.00mg); Calcium Pantothenate (10,000.00mg);Vitamin B6 (4,000.00mg); Vitamin B12 (20.00mg); Choline Chloride (300,000.00mg); Folic Acid $(1,000.00 \mathrm{mg})$; Biotin (50.00mg); Manganese (300,000.00mg); Iron (120,000.00); Zinc (80,000.00mg); Copper (8,500.00mg); Iodine (1,500.00mg); Cobalt (300.00mg); Selenium (120.00); Anti-Oxidant (120,000.00mg

Table 2: The main effect of pen colour on performance of finisher gilts

\begin{tabular}{|c|c|c|c|c|c|}
\hline \multirow[t]{2}{*}{ Parameters } & \multicolumn{4}{|c|}{ Colour } & \multirow[t]{2}{*}{ SEM } \\
\hline & $\begin{array}{l}\text { Control } \\
\text { (grey) }\end{array}$ & Red & Blue & Green & \\
\hline Initial weight(kg)/pig & 38.22 & 38.11 & 38.00 & 38.22 & 0.10 \\
\hline Final weight $(\mathrm{kg}) / \mathrm{pig}$ & $57.00^{\mathrm{b}}$ & $57.78^{\mathrm{ab}}$ & $57.67^{\mathrm{ab}}$ & $58.67^{\mathrm{a}}$ & 1.07 \\
\hline $\begin{array}{l}\text { Average weight }(\mathrm{kg}) \\
\text { gain/pig/week }\end{array}$ & $2.68^{\mathrm{b}}$ & $2.81^{\mathrm{ab}}$ & $2.81^{\mathrm{ab}}$ & $2.92^{\mathrm{a}}$ & 0.03 \\
\hline $\begin{array}{l}\text { Average } \\
\text { feed(kg)intake/pig/week }\end{array}$ & 13.22 & 13.56 & 13.22 & 13.89 & 0.84 \\
\hline Feed conversion ratio & 4.92 & 4.83 & 4.92 & 4.76 & 0.19 \\
\hline
\end{tabular}

different $(\mathrm{p}>0.05)$ for gilts in green, blue and red pens $(2.92 \pm 0.13 \mathrm{~kg}, 2.81 \pm 0.21$ and $2.81 \pm 0.19 \mathrm{~kg}$ respectively) but heavier compared to those observed in the control $(2.68 \pm 0.17 \mathrm{~kg})$ pen. There was no significant variation $(p>0.05)$ in FCR values of the gilts across the treatments.

From the results presented in Table 3, there were significant $(\mathrm{p}<0.05)$ differences in the final weight per week of the gilts across the treatments with those in $12 \mathrm{~h}$ and $15 \mathrm{~h}$ pens having the highest final weight of $58.33 \pm 1.23 \mathrm{~kg}$ and $58.00 \pm 1.13 \mathrm{~kg}$, respectively. There were no significant $(p>0.05)$ variation in the average weight gain per week of the gilts under the 


\section{Effects of pen colour and photoperiod interactions on finisher gilts}

photoperiods with 12 and $15 \mathrm{~h}$ having values of $2.89 \pm 0.14 \mathrm{~kg}$ and $2.82 \pm 0.18 \mathrm{~kg}$ respectively compared to those in the $18 \mathrm{~h}$ photoperiod with $2.70 \pm 0.21 \mathrm{~kg}$. The feed intake of gilts under $12 \mathrm{~h}$ photoperiod $(14.58 \pm 0.99 \mathrm{~kg})$ were also significantly $(p<0.05)$ higher than those under 15 and $18 \mathrm{~h}$ photoperiods $(13.17 \pm 0.68 \mathrm{~kg}$ and
$12.67 \pm 0.65 \mathrm{~kg}$, respectively). There were also significant differences $(p<0.05)$ in the feed conversion ratio across the photoperiods with $15(4.68 \pm 0.25)$ and $18 \mathrm{~h}$ (4.70 \pm 0.22 ) having better FCR compared to those on $12 \mathrm{~h}(5.05 \pm 0.37)$,

Table 3: The main effect of photoperiod on performance characteristics of finisher gilts

\begin{tabular}{|c|c|c|c|c|}
\hline \multirow[t]{2}{*}{ Parameters } & \multicolumn{3}{|c|}{ Time } & \multirow[t]{2}{*}{ SEM } \\
\hline & $12 \mathrm{~h}$ & $15 \mathrm{~h}$ & $18 \mathrm{~h}$ & \\
\hline Initial weight $(\mathrm{kg}) /$ pig & 38.08 & 38.25 & 38.08 & 0.15 \\
\hline Final weight $(\mathrm{kg}) /$ pig & $58.33^{\mathrm{a}}$ & $58.00^{\mathrm{a}}$ & $57.00^{\mathrm{b}}$ & 0.21 \\
\hline Average weight(kg) gain/pig/week & $2.89^{\mathrm{a}}$ & $2.82^{\mathrm{ab}}$ & $2.70^{\mathrm{b}}$ & 0.03 \\
\hline Average feed(kg)intake/pig/week & $14.58^{\mathrm{a}}$ & $13.17^{\mathrm{b}}$ & $12.67^{\mathrm{b}}$ & 0.18 \\
\hline Feed conversion ratio & $5.05^{\mathrm{a}}$ & $4.68^{\mathrm{b}}$ & $4.70^{\mathrm{b}}$ & 0.05 \\
\hline
\end{tabular}

The effect of pen colour on rectal temperature of the gilts is shown in Figure 1. The gilts in red pens had average rectal temperature of $39.65 \pm 0.41^{\circ} \square$, while their counterparts in green, control and blue pens had average rectal temperature of $39.61 \pm 0.20^{\circ} \square, \quad 39.56 \pm 0.22^{\circ} \square$ and $39.48 \pm 0.63^{\circ} \square$ respectively.

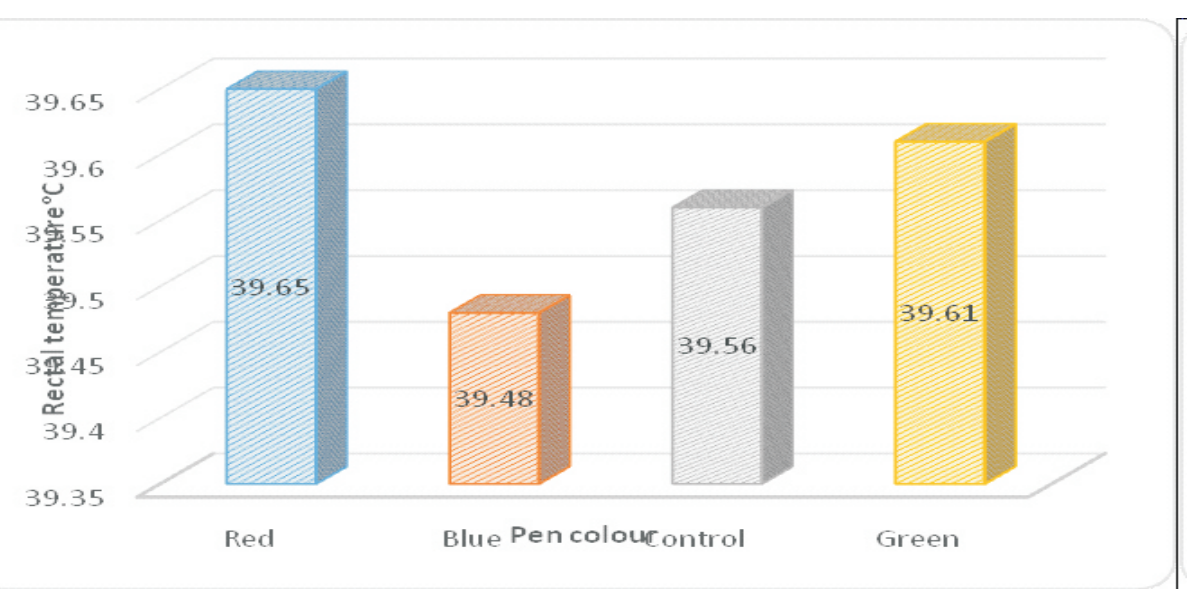

Figure 1: The effect of pen colour on rectal temperature of finisher gilts

The effect of pen colour on respiratory rate of gilts at finisher stage is shown in Figure 2. There were significant variations $(p<0.05)$ in the values of average respiratory rate across the treatments. The average respiratory rate for gilts in the red and green pens were $46.64 \pm 4.05$ and $46.24 \pm 2.32 \mathrm{breath} / \mathrm{minute}$ while those in the blue and control pens were $45.84 \pm 3.55$ and $45.62 \pm 3.21 \mathrm{breath} / \mathrm{min}$, respectively. 
Adelowo, Adebiyi and Odu

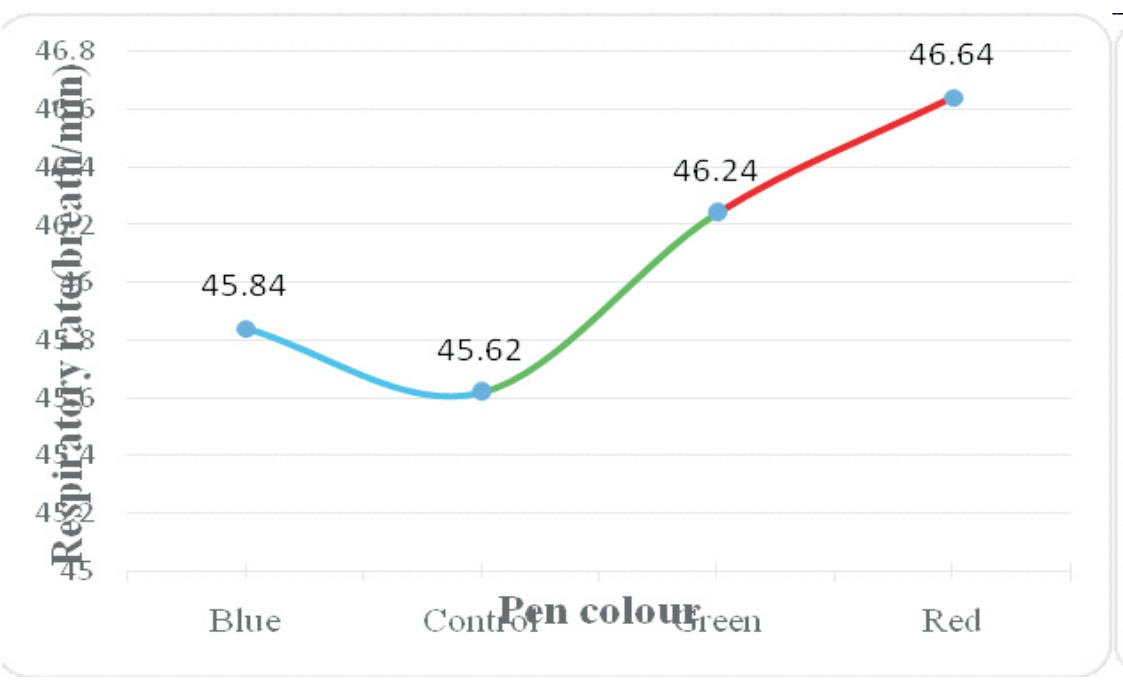

Figure 2: The Effect of pen colour on respiratory rate of finisher gilts

Table 4: Interaction of pen colour $x$ photoperiod on performance of finisher gilts

\begin{tabular}{|c|c|c|c|c|c|c|}
\hline Photoperiod & Colour & IWT(kg) & FWT(kg) & AWG(kg) & $\mathrm{FI}(\mathrm{kg})$ & FCR \\
\hline & Control & $38.00 \pm 0.01$ & $58.00 \pm 1.00^{\mathrm{ab}}$ & $2.86 \pm 0.14^{\mathrm{ab}}$ & $14.67 \pm 1.15^{\mathrm{a}}$ & $5.13 \pm 0.22^{\mathrm{a}}$ \\
\hline \multirow[t]{4}{*}{$12 \mathrm{~h}$} & Red & $38.00 \pm 1.00$ & $57.67 \pm 2.08^{b}$ & $2.81 \pm 0.22^{\mathrm{ab}}$ & $14.00 \pm 0.01^{\mathrm{ab}}$ & $5.00 \pm 0.40^{\mathrm{a}}$ \\
\hline & Blue & $38.00 \pm 1.00$ & $58.67 \pm 0.58^{\mathrm{ab}}$ & $2.95 \pm 0.08^{\mathrm{a}}$ & $14.33 \pm 0.01^{\mathrm{ab}}$ & $4.86 \pm 0.47^{\mathrm{ab}}$ \\
\hline & Green & $38.33 \pm 0.58$ & $59.00 \pm 1.00^{\mathrm{a}}$ & $2.95 \pm 0.08^{\mathrm{a}}$ & $15.33 \pm 1.15^{\mathrm{a}}$ & $5.20 \pm 0.48^{\mathrm{a}}$ \\
\hline & Control & $38.33 \pm 0.58$ & $57.00 \pm 1.00^{\mathrm{bc}}$ & $2.67 \pm 0.08^{b}$ & $13.00 \pm 0.01^{\mathrm{b}}$ & $4.88 \pm 0.15^{\mathrm{ab}}$ \\
\hline \multirow[t]{4}{*}{$15 \mathrm{~h}$} & Red & $38.33 \pm 0.58$ & $58.33 \pm 1.52^{\mathrm{ab}}$ & $2.86 \pm 0.29^{\mathrm{ab}}$ & $13.33 \pm 1.15^{\mathrm{b}}$ & $4.67 \pm 0.22^{b}$ \\
\hline & Blue & $37.97 \pm 0.58$ & $58.00 \pm 1.00^{\mathrm{ab}}$ & $2.90 \pm 0.14^{\mathrm{a}}$ & $13.00 \pm 0.01^{\mathrm{b}}$ & $4.49 \pm 0.26^{b c}$ \\
\hline & Green & $38.67 \pm 0.58$ & $58.67 \pm 0.58^{\mathrm{ab}}$ & $2.86 \pm 0.14^{\mathrm{ab}}$ & $13.33 \pm 0.58^{\mathrm{b}}$ & $4.67 \pm 0.30^{b}$ \\
\hline & Control & $38.33 \pm 0.58$ & $56.00 \pm 1.00^{\mathrm{c}}$ & $2.52 \pm 0.08^{b}$ & $12.00 \pm 0.01^{\mathrm{c}}$ & $4.76 \pm 0.16^{b}$ \\
\hline \multirow[t]{3}{*}{$18 \mathrm{~h}$} & Red & $38.00 \pm 0.01$ & $57.33 \pm 0.58^{b}$ & $2.76 \pm 0.08^{b}$ & $13.33 \pm 0.58^{\mathrm{b}}$ & $4.83 \pm 0.06^{b}$ \\
\hline & Blue & $38.33 \pm 0.58$ & $56.33 \pm 0.58^{\mathrm{c}}$ & $2.57 \pm 0.14^{b}$ & $12.33 \pm 0.58^{\mathrm{c}}$ & $4.80 \pm 0.14^{b}$ \\
\hline & Green & $37.97 \pm 0.58$ & $58.33 \pm 0.58^{\mathrm{ab}}$ & $2.95 \pm 0.16^{\mathrm{a}}$ & $13.00 \pm 0.01^{\mathrm{b}}$ & $4.41 \pm 0.24^{\mathrm{c}}$ \\
\hline
\end{tabular}

\section{Discussion}

The gilts in the green, blue and red pens were observed to have the highest final weight which suggested that these colours were actually visible to the eye of the gilts. These results, equally supports the findings of Neitz and Jacobs (1989) that the retina of pigs contains a substantial population of two types of cones with sensitivity peaks at about $439 \mathrm{~mm}$ (indigo) and $556 \mathrm{~mm}$ (green-yellow) in the spectrum of visible light, which led to the conclusion that pigs have dichromatic colour vision. It also supports the findings of Taylor (2010) that pigs have vision for a wide range of tasks from foraging to communication, discriminating between individuals, and socio learning. The authors further reported that the pig's eye has two sets of cones that give the animal peak wavelength sensitivity at $439 \mathrm{~nm}$ (blue colour) and $556 \mathrm{~nm}$ (green colour). Tanida et al. (1991) found that pigs can identify 'blue', but suggested that pigs discriminated blue from other colours on 


\section{Effects of pen colour and photoperiod interactions on finisher gilts}

the basis of hue rather than brightness and may be red-green colour blind. But this is at variance with the results obtained in our earlier study on gilts at the weaner and grower stages in which the gilts in the red pen were observed to consume more and had the highest weight gain and final weight (Adelowo and Adebiyi, 2016; Adebiyi and Adelowo, 2017). The calmness of the gilts in green and blue pens at this stage resulted in better build-up of body mass and this corroborated earlier findings (Nicol and Pope, 1994; Croney et al., 2003) that in pigs vision is used to some extent during foraging and that they have the ability to recognise and associate a colour with food source. The findings of Hendrickson and Hicks (2002) also supports this result which explained that pigs have both $\mathrm{S}$ and $\mathrm{M}$ cone types found throughout their retina, and almost all regions had mean $\mathrm{S}$ cone percentage greater than $10 \%$ and the $\mathrm{S}$ cone density is significantly higher than that in humans, which potentially enables the pig to be more sensitive to blue wavelengths than the human over a larger area of the retina.

Natural light is a factor in pig production that cannot be underestimated, as it had significant effect in productivity, wellbeing and overall performance of pigs (Rivera et al., 2005, Adebiyi and Adelowo, 2017). In the present study, growth of the gilts was found to be increasing as photoperiod is reduced. The findings also support the results of Dureau et al. (1996), Adelowo and Adebiyi (2016), and Adelowo et al. (2018) who reported that animals experiencing four or more weeks of continuous illuminance lost up to $20 \%$ body weight, indicating either behavioural disinclination to eat due to stress associated with the extreme lighting conditions.

The interaction of the pen colour and the photoperiod had positive effect on the gilt's performance as observed in the average weight gain and final weight of the gilts in 12 and 15 hour photoperiods.

\section{Conclusion}

Rearing gilts at finisher stage in green, blue or red pen gives best results in terms of growth performance and higher weight gain. At the finisher stage increasing the photoperiod with artificial light will not increase the growth nor better the utilisation of the feeds consumed by the gilts. But the interaction of the pen colour and photoperiod at 12-hour photoperiod will enhance performance by increasing weight gain and final weight of the gilts at this stage.

\section{Ethical declaration}

All authors hereby declare that "Principles of laboratory animal care" (NIH publication No. 85-23, revised 1985) were followed, as well as specific national laws where applicable.

\section{Acknowledgement}

The authors will like to acknowledge the Tertiary Education Trust Fund (TETFUND), Nigeria for sponsoring this research work.

\section{Competing interests}

Authors have declared that no competing interests exist.

\section{References}

Adebiyi, O. A. and Adelowo, O. V. 2017. Photoperiodism and pen colouration: effects on the performance characteristics of growing gilts. Nigerian Journal of Animal Production, 44(3): 89-97.

Adelowo, O. V., Adebiyi, O. A. and Peters, S. O. 2018. Influence of Varied Photoperiod on the Physiology and Growth Performance of Gilts at Finisher Stage Raised in the 
Humid Tropics. In Atteh, J. O., Belewu, M. A., Fayeye, T. R., Okukpe, K.M, Alli, O. I and Adeyemi, K.D. Development of a Resilient Livestock industry for National Economic Growth. The proceedings of the $7^{\text {th }} A S A N$ NIAS Joint Annual Meeting, Ilorin 2018. Pg: 177-180. ISSN9783477722

Adelowo, O. V. 2017. Effects of Pen colour and Photoperiods on swine behaviour and production (unpublished PhD thesis submitted to the Department of Animal Science, University of Ibadan)

Adelowo, O. V. and Adebiyi, O. A. 2016. The Effect of Pen Colour and Increased Photoperiod on Performance of Weaned Gilts. British Biotechnology Journal 16(2): 1-7.

Andersson, H., Rydhmer, L., Lundstrom, K., Wallgren, M., Andersson, K. and Forsberg, $M$. 1998. Influence of artificial light regimens on sexual maturation and boar taint in entire male pigs. Animal Reproduction Science, 51: 31-43.

Croney, C. C., Adams, K. M., Washington, M. G. and Stricklin, W. R. 2003. A note on visual, olfactory and spatial cue use in foraging behaviour of pigs: indirectly assessing cognitive abilities. Applied Animal Behaviour Science. 83: 303-308.

Delabbio, J. 2015. Led lighting programs for Enhancement of Swine performance. The Science of Swine Vision. Once innovations I n c . P g . 1 - 5 https://www.once.group/.../Scienc e-of-Swine
Dureau, P., Jeanny, J. C., Clerc, B., Dufier, J. L. and Courtois, Y. 1996. Long term light - induced retinal degeneration in the miniature pig. Molecular Vision 2(7):Pp.198- 204.

Hendrickson, A., and Hicks, D. (2002). Distribution and density of medium- and short wavelength selective cones in the domestic pig retina. Experimental Eye Research. 74 (4) p435-444.

Morley, C., Hewson, P., Thorton, A. and Cole, T. 1992. Axillary and rectal temperature measurements in infants. Arch Dis Child. 67(1):1225.

Neitz, J. and Jacobs, G. H. 1989. Spectral sensitivity of cones in an ungulate. Visual Neuroscience. 2: pp.97 100.

Nicol, C. J. and Pope, S. J. 1994. Sociallearning in sibling pigs. Applied Animal Behaviour Science.40 (1) p $31-43$.

NRC 1998. Nutrient Requirements of Swine: $10^{\text {th }}$ Revised Edition Wa shington, D C S u b Committee on Animal Nutrition, National Research Council $8.5 \mathrm{x}$ 11,210 pages https:// www.nap.edu/.../nutrient

Prince, H. 1977. The eye and vision. In: Swenson MJ (Ed.). Dukes Physiology of Domestic Animals. Ithaca, NY: Cornell University Press, pp. 696-712.

Rivera, M. M., Quintero-Moreno, A., Barrera, X., Palomo, M. J., Rigau, T. and Rodríguez-Gil, J. E. 2005. Natural mediterranean photoperiod does not affect the main parameters of boar - semen $\mathrm{q} \mathrm{u}$ a $1 \mathrm{it}$ y a $\mathrm{n}$ a $1 \mathrm{y} \mathrm{s} \mathrm{i}$ s. Theriogenology.64:934-946. 
Sancho, S., Rodriguez-Gil, J. E., Pinart, E., Briz, M., Garcia-Gil, N., Badia, E., Bassols, J., Pruneda, A., Bussalleu, E., Yeste, M., Casas, I., Palomo, M. J., Ramio, L. and Bonet, S. 2006. Effects of exposing boars to different artificial light regimens on semen plasma markers and "in vivo" fertilizing capacity. Theriogenology 65:317-331.

Signoret, A., Baldwin, A., Fraser, D., and Hafez, E. (1975). The behavior of swine. In: Hafez ESE (ed.). 1975. The Behaviour of Domestic Animals, 3rd edn. Baltimore, MD: Williams \& Wilkins, pp. 295-329.
SAS 2010. SAS/STAT User's Guide: Version 9.2. SAS Institute Inc., Cary. NC., USA, 2010.

Tanida, H., Senda, K. I., Suzuki, S., Tanaka, T. and Yoshimoto, T. 1991. Color discrimination in weanling pigs. Animal Science and Technology(Japan). 62 (11) p10291034.

Taylor, N. R. 2010. Lighting for pig units. Report compiled for BPEX.

Received: $14^{\text {th }}$ September, 2018

Accepted: $19^{\text {th }}$ December, 2018 